\title{
Effects of Different Soil Conditioners on Water Use Efficiency and Tomato Plant Growth in Loam and Clay Loam Soils
}

\author{
Nurten İşler* (iD Yasemin Kavdır iD \\ Çanakkale Onsekiz Mart University, Department of Soil Science and Plant Nutrition, Faculty of Agriculture, Çanakkale, \\ Turkey. \\ *Corresponding author: nurtenisler83@gmail.com
}

Geliş Tarihi: 08.04.2021

Kabul Tarihi: 26.05.2021

\begin{abstract}
Experiment was consisted of two different soil textures (clay loam and loam), four treatments ( $8 \%$ olive pomace compost, $4 \%$ perlite, $0.12 \%$ hydrophilic polymers and control) with three replications. Tomato (Lycopersicon lycopersicum L.) seedlings were transferred to each pot and plants were grown under controlled atmosphere conditions. Effects of different soil conditioners on plant water use efficiency and tomato plant growth were determined. As a result, olive pomace compost applications to loam soil saved irrigation water $45.12 \%, 42.99 \%$ and $38.88 \%$ compared to control, perlite and hydrophilic polymers treatments respectively. On the other hand, hydrophilic polymers treatments saved irrigation water $17.82 \%, 46.76 \%$ and $27.29 \%$ compared to control, perlite and olive pomace compost treatments respectively for clay loam soil. Soil $\mathrm{pH}$ decreased and electrical conductivity (EC) increased for both soils after the experiment. The highest soil EC value was detected with the application of olive pomace compost. Perlite application increased plant fresh weight and length while olive pomace compost increased branch numbers of tomato for clay loam soil. Root length and surface areas were maximum under olive pomace compost applications for both soils.
\end{abstract}

Keywords: Soil conditioner, water use efficiency, tomato, olive pomace compost, hydrophilic polymers

\section{Farklı Toprak Düzenleyicilerin Tın ve Killi Tın Topraklarda Su Kullanım Randımanına ve Domates Bitkisinin Büyümesine Etkileri \\ Öz}

Bu çalışma iki farklı tekstür (tın ve killi tın), dört farklı uygulama (kontrol, \% 8 pirina kompostu, $\% 4$ perlit ve $\% 0.12$ su tutucu polimer) ve üç tekerrürden oluşmaktadır. Bitki büyüme odasında yürütülen bu çalışmada, toprak düzenleyicilerin toprak nemine, bazı toprak özelliklerine ve domates bitkisinin (Lycopersicon lycopersicum $L$.) bazı bitkisel özelliklerine etkileri belirlenmiş̧ir. Çalışma sonucunda, tınlı toprakta pirina kompostu uygulamasına kontrol, perlit ve su tutucu polimer uygulamalarına göre sirasıyla \% 45.12, \% 42.94 ve $\% 38.88$ oranında daha az sulama suyu verilmiştir. Killi tın toprakta ise su tutucu polimer uygulaması ile kontrol, perlit ve pirina kompostu uygulamalarına göre sirasıyla \% 17.82, \% 46.76 ve pirina $\% 27.29$ oranında daha az sulama suyu verilmiştir. Deneme sonunda her iki toprakta da $\mathrm{pH}$ düşmüş ve elektriksel iletkenlik (EC) artmıştır. En yüksek EC pirina kompostu uygulamasında bulunmuştur. Killi tın toprakta en fazla bitki yaş ağırlığı ve bitki boyu perlit uygulamasında, en fazla bitki dal sayısı pirina kompostu uygulamasında bulunmuştur. Her iki toprakta da en fazla kök uzunluğu ve kök alanı pirina kompostu uygulamasında olmuştur.

Anahtar kelimeler: Toprak düzenleyici, su kullanım randımanı, domates, pirina kompostu, su tutucu polimerler

\section{Introduction}

Drought has been dramatically increasing across the worldwide and therefore water must be used more efficiently. Adding certain organic substances and soil conditioners particularly into sandy soils with low aggregate stability and water holding capacity improves the water retention capacity of such soils (Brady and Weil, 2008). There are many types of organic or inorganic substances available that may be used to regulate soil water properties. However; these substances should not be harmful to environment and plant development. Perlite and hydrophilic polymers are inorganic soil conditioners and they are widely available in markets. Perlite is a volcanic glass containing more than $1 \%$ water. and it softens when it reaches temperatures of $800-900{ }^{\circ} \mathrm{C}$. Perlit's volume increases about 20 times of its original volume to create an expanded and porous material when it is heated rapidly (Yurkov and 
Aksel'rod, 2005) Initial research on synthetic polymers showed great promise in improving soil aggregation, soil water holding capacity and prevent erosion (Wallace and Wallace, 1986). Gelforming, cross-linked polyacrylamides can be used to overcome short term or persistent drought which inhibits plant growth (Johnson, 1984). Hydrogels absorb and store water hundreds of times their own weight (Bowman and Evans, 1991). The uses of alternative water holding amendments and irrigation methods will become more important, especially in regions have water scarcity on the other hand they are too expensive for widespread use (Wallace and Wallace, 1986). The correct use of hydrophilic polymers has great importance for agricultural production especially under drought and semi-drought climates because it diminishes the negative effects of water-scarcity (Han et al., 2010). Direct use of olive pomace restricts the plant's development that is because phenol substances and organic fatty acids contained in the plant cannot transform into humic substances (Ilay et al., 2013). Therefore, olive pomace should be used in agriculture after making compost (Gonzalez et al., 1990; Kavdır and Killi, 2008) which is ecologically friendly soil conditioner and it can be used as a considerable source for increasing the carbon content in soil and improving soil aggregate stability (Kavdır and Killi, 2008). Addition of olive pomace compost (OPC) to sandy clay loam soil increased available water for plant growth and improved hydraulic characteristics of soils. Results suggest that OPC may also serve as effective organic conditioner to improve soil hydraulic properties (Killi et al., 2014).

The fact that the ratio of water and air in the soil is within certain limits is very important in terms of normal development of the plants. For this reason, it is necessary to control the amount of water in the root zone and to determine irrigation amount accurately. Direct and indirect methods can be used to determine soil water contents. Using FDR sensor (Leib et al., 2003) does not require much labor, save time and can be placed at desired soil depth.

The aim of this research was to determine effects of different soil conditioners on soil properties (water contents, $\mathrm{pH}$ and electrical conductivity), tomato plant growth (the number of branches, plant height and fresh weights, plant water use efficiency, root parameters) and total irrigation water amount.

\section{Materials and Methods}

\section{Properties of soils used in the study}

Loam and clay loam soil samples were taken from 0-20 cm soil depths from Çanakkale Onsekiz Mart University-Dardanos Campus and Lapseki province in Çanakkale. Texture, pH, electrical conductivity (EC), field capacity, bulk density and wilting point of these soil samples are presented in Table 1.

Table 1. Some physical and chemical properties of soils

\begin{tabular}{|c|c|c|c|c|c|c|c|c|c|}
\hline Soil & $\begin{array}{l}\mathrm{S} \\
\text { and } \\
(\%)\end{array}$ & $\begin{array}{r}\mathrm{Si} \\
\text { lt }(\%)\end{array}$ & $\begin{array}{l}\mathrm{C} \\
\text { lay } \\
(\%)\end{array}$ & $\begin{array}{l}\text { Tex } \\
\text { ture }\end{array}$ & $\begin{array}{r}\mathrm{pH} \\
(1: 2.5)\end{array}$ & $\begin{array}{c}\mathrm{EC} \\
\begin{array}{c}(\mu \mathrm{S} \\
\left.\mathrm{cm}^{-1}\right)\end{array} \\
\end{array}$ & $\begin{array}{l}\text { Bulk } \\
\text { density } \\
\left(\mathrm{g} \mathrm{cm}^{-3}\right)\end{array}$ & $\begin{array}{c}\text { Field } \\
\text { Capacity } \\
\text { PV (\%) }\end{array}$ & $\begin{array}{l}\text { Wilting } \\
\text { Point } \\
\text { PV (\%) }\end{array}$ \\
\hline${ }_{\mathrm{ki}}$ Lapse & $\begin{array}{r}4 \\
9.95\end{array}$ & $\begin{array}{r}2 \\
8.51\end{array}$ & $\begin{array}{r}2 \\
1.54\end{array}$ & $\mathrm{~L}$ & $5^{8.0}$ & $\begin{array}{l}115.8 \\
0\end{array}$ & 1.42 & 33.74 & 15.08 \\
\hline $\begin{array}{l}\text { Darda } \\
\text { nos }\end{array}$ & $\begin{array}{r}3 \\
5.82 \\
\end{array}$ & $\begin{array}{r}2 \\
4.91 \\
\end{array}$ & $\begin{array}{r}3 \\
9.27\end{array}$ & CL & $\begin{array}{l}7.7 \\
7\end{array}$ & $\begin{array}{l}201.9 \\
0\end{array}$ & 1.30 & 47.74 & 18.53 \\
\hline
\end{tabular}

\section{Properties of olive pomace compost}

The olive pomace compost (OPC) was prepared by using olive pomace $(50 \%), 30 \%$ poultry manure, $10 \%$ alfalfa, $5 \%$ olive leaves, $5 \%$ soil and approximately $5 \mathrm{~L}$ of water was added in the composting bins. Some chemical parameters of the olive pomace compost areas follow; $\mathrm{pH}: 8.83$, EC: $2830 \mu \mathrm{S} \mathrm{cm}^{-1}$, C: $27.10 \%, \mathrm{~N}: 1.74 \%, \mathrm{C}: \mathrm{N}$ ratio: 15.57 .

\section{Experimental design and planting}

Lycopersicon esculentum Mill. cv. H-2274 was selected as the tomato varieties. Peat was selected as the germination media. Three seeds were planted in each seedling pots and they were placed to incubator at $22^{\circ} \mathrm{C}$ for germination experiment. The seeds started to germinate eight days 
after sowing. Soils were sieved through a $6 \mathrm{~mm}$-sieve and olive pomace compost $(8 \% \mathrm{w} / \mathrm{w})$, perlite $(4 \%)$, and hydrophilic polymer $(0.12 \%)$ were mixed with soils and placed in pots (3-L volume). Average size of OPC and perlites were $2 \mathrm{~mm}$ and between $2-4 \mathrm{~mm}$ respectively. Soil without any amendment was used as a control treatment and all treatments were replicated three times. Tomato seedlings were transplanted in the pots and then they were placed to growth chamber as a randomized block design. Plant growth chamber's temperatures were set between $24-27^{\circ} \mathrm{C}$ and humidity's were between $70-75 \%$ during the experiment. Plants were grown for 27 days and then above ground parts of tomato plants were cut from soil surface and fresh weights were determined.

\section{Fertilization}

Mono ammonium phosphate (MAP) and potassium sulphate (PS) fertilizer solutions were prepared in accordance with the ratios of $300 \mathrm{~kg} \mathrm{ha}^{-1} \mathrm{~N}, 150 \mathrm{~kg} \mathrm{ha}^{-1} \mathrm{P}$ and $600 \mathrm{~kg} \mathrm{ha}^{-1} \mathrm{~K}$. Fertilizer solutions were applied at planting and it was applied several times with the irrigation water during the experiment.

\section{Soil moisture data recording}

Loam and clay loam soils were sieved through a $6 \mathrm{~mm}$ sieve and filled into $3000 \mathrm{~cm}^{3}$-pots. Previously their water content at saturated conditions and at field capacity were determined in order to calculate the quantity of the irrigation water (Table 2). The moisture change was measured with the help of FDR sensors. Moisture sensors were calibrated by adapting the technique recommended by Starr and Paltineanu (2002). Weight of pots including soil and water was recorded. FDR sensors were placed in soil vertically and calibrated for each soil texture and soil plus conditioners mixtures The coefficient of determination $\left(\mathrm{R}^{2}\right)$ was found to be over 0.90 for all treatments. The data measured by the sensors were stored by data recorders with hourly intervals. The stored data were transferred from the data recorders to the computer through USB connection (Demirel and Kavdır, 2013). Irrigation water quantity was determined by using the calibration data in accordance with the Equation (1). Inadequate amount was calculated by subtracting current moisture from field capacity (Table 2) value. Unit was converted from percentage to $\mathrm{ml}$ by using soil weights in the pots. The quantity of decreased water is determined with 5-day intervals in $\mathrm{ml}$.

$d n=F C-C M$

In the equation; dn: net quantity of irrigation water $(\mathrm{ml}), \mathrm{FC}$ : field capacity $(\%) \mathrm{CM}$ : current moisture $(\%)$

Table 2. Field capacity, wilting point and available water contents for loam and clay loam soil

\begin{tabular}{lcccccc}
\hline \multirow{2}{*}{ Treatments } & \multicolumn{2}{c}{ Field Capacity } & \multicolumn{2}{c}{ Wilting Point } & \multicolumn{2}{c}{ Available Water Content } \\
& \multicolumn{2}{c}{ PV (\%) } & \multicolumn{2}{c}{ PV $(\%)$} & \multicolumn{2}{c}{ PV $)$} \\
\cline { 2 - 7 } & Loam & Clay loam & Loam & Clay loam & Loam & Clay loam \\
\hline Control & 20.79 & 31.46 & 10.72 & 18.58 & 10.07 & 12.88 \\
Perlite & 23.93 & 30.26 & 13.70 & 19.47 & 10.23 & 10.79 \\
Olive pomace compost & 29.07 & 35.52 & 17.86 & 22.66 & 11.21 & 12.87 \\
Hydrophilic polymer & 22.99 & 34.16 & 12.17 & 19.49 & 10.82 & 14.67 \\
\hline
\end{tabular}

PV: percent by volume

\section{Determination of evaporation}

In order to determine evaporation, a certain amount of water was filled into an approximately $3000 \mathrm{~cm}^{3}$ vessel and water height was measured every single day during the testing period; and the evaporation was determined according to the amount of water decreased.

\section{Soil analytical methods}

Gravimetric water content was determined by the difference between moist weight and ovendried (at $105{ }^{\circ} \mathrm{C}$ for $24 \mathrm{~h}$ ) weights of soil samples. Soil $\mathrm{pH}$ was determined through the potentiometric measurement of the hydrogen ion concentration in 1:2.5 soil-water mixture with a pH meter (İnoLab, WTW); and the electrical conductivity through the electrical conductivity method with an EC meter (Crison CM-35) (Black, 1965). Compost pH and EC were measured in 1:10 compost-water mixture. Soil texture was determined using the hydrometer method (Gee and Bauder, 1986). Field capacity and wilting point determined with the help of pressure chambers (Soil Moisture Equipment Corp, USA). Field capacity value ranges between $10 \mathrm{kPa}$ (Romano and Santini, 2002) and $33 \mathrm{kPa}$ (Orfánus and Eitzinger, 2010) depending on soil texture. 


\section{Plant measurements and analysis}

The number of branches of tomato plants was determined by counting, Tomato plants were cut from the soil surface and the height was determined by measuring with a ruler.

\section{Root analytical methods}

The roots were pulled and removed from soils. Roots were placed in a container filled with water and they were filtered through $0.163 \mathrm{~mm}$ sieve. This process has continued several times. Root parameters such as root length $(\mathrm{cm})$ and root surface area $\left(\mathrm{cm}^{2}\right)$ were determined in digitized root images using WinRhizo Basic 2007 (Regent Inst) program.

\section{Water use efficiency}

Water use efficiency was calculated with the help of the equation 2.

$$
W U E=P F W / Q I W P
$$

In the equation: WUE: Water Use Efficiency, PFW: Plant's Fresh Weight (g), QIWP: Quantity of Irrigation Water Provided (ml).

\section{Statistical analysis}

Duncan test was conducted to provide significant differences $(\mathrm{P}<0.05)$ between $\mathrm{pH}, \mathrm{EC}$, quantity of irrigation water applied, tomato plant's fresh weight. Analysis was conducted by using SAS programme (SAS, 1999).

\section{Results and Discussion}

\section{Effects of different soil conditioners on soil water}

In this study, the coefficient of determination $\left(\mathrm{R}^{2}\right)$ was found to be over 0.90 for all treatments. Cardenas-Lailhacar and Dukes (2010) reported the positive relation between the volumetric water content obtained from FDR sensors and the water content determined through the gravimetric method in their study. They found the average $\mathrm{R}^{2}$ value was 0.934 that was close to our data. Starr and Paltineanu (1998) reported that the correlation coefficient was 0.992 in their study. Fazackerley and Lawrence (2010), compared the amount of controlled irrigation water used under normal conditions and controlled irrigation water with the help of FDR sensors. They reported that they saved $47 \%$ of water as a result of the study.

Control soils received the highest amount of dn and followed by P, HP and OPC respectively (Table 3). The difference among treatments were found to be statistically significant in terms of dn for loam soil $(\mathrm{P}<0.05)$. Total quantity of irrigation water applied to the OPC treatment was significantly lower than other treatments. OPC treatment received $45.12 \%, 42.94 \%$ and $38.88 \%$ less irrigation water compared to control, P and HP treatments respectively. Conservation of soil moisture by application of OPC has also been reported by other researchers. Bouranis et al. (1995) reported that the water retention capacity of the soil mixed with the compost composed of olive oil waste water and olive oil solid waste would be two times more in comparison with pure soil. El-Asswad et al. (1993) mentioned that addition of oil cake significantly increased $(\mathrm{p} \leq 0.05)$ the water retention of two sandy soils studied under all applied tensions. P treatment saved 3.83\%, HP treatments saved $10.22 \%$ water compared to control treatment for loam soil. Effects of treatments for clay loam soil was found to be significant in terms of total dn applied $(\mathrm{P}<0.05)$ (Table 3). Total dn of $\mathrm{P}$ treatment was greater than $\mathrm{dn}$ of other treatments for clay loam soils. P treatment received $46.76 \%, 35.22 \%$ and $26.78 \%$ more water than HP, control and OPC treatments respectively (Table 3). Amendments of oversize fragments such as large granules of perlite will increase the air-filled porosity (Caron et al., 2005) and drainage. Evans and Gachukia (2007) mixed different ratios of perlite to rice hulls and when perlite ratio increased from $20 \%$ to $60 \%$ and water holding capacity reduced from $67.9 \%$ to $59.0 \%$. HP treatment received the lowest quantity of irrigation water for clay loam soil. It saved $17.82 \%, 46.76 \%$ and $27.29 \%$ irrigation water compared to control, OPC and P respectively. The variations in hydrophilic polymers effects on soil water characteristics and plant growth changes according to type of hydrophilic polymers, plant types and soils (Akhter et al, 2004). Several studies (Abedi-Koupai and Asadkazemi, 2006; López-Elías et al., 2013; Yang et al., 2014; Mazen et al., 2013). have reported that applications of hydrophilic polymers increased soil water holding capacities. 
Table 3. Quantity of irrigation water applied to loam and clay loam soil.

\begin{tabular}{lcc}
\hline \multirow{2}{*}{ Treatments } & \multicolumn{2}{c}{ Total irrigation water applied (ml) } \\
\cline { 2 - 3 } Control & Loam & Clay loam \\
Perlite & $1374.80 \pm 113.85 \mathbf{A}$ & $597.52 \pm 78.37 \mathbf{B}$ \\
Olive pomace compost & $1322.23 \pm 78.50 \mathbf{A}$ & $922.31 \pm 59.02 \mathbf{A}$ \\
Hydrophilic polymer & $754.50 \pm 29.33 \mathbf{B}$ & $675.37 \pm 24.17 \mathbf{B}$ \\
\hline
\end{tabular}

Differences between the averages specified with different capital letters in the same column are significant and they indicate the difference between treatments $(n=3, P<0.05)$.

\section{Effects of different soil conditioners on $\mathrm{pH}$ and EC of soils}

Average $\mathrm{pH}$ and EC values were reported at Table 4. The differences among treatments for loam soil and clay loam soil were statistically significant $(\mathrm{p}<0.05)$. An initial $\mathrm{pH}$ value was 8.05 in loam soil (Table 1) and it ranged between 7.48-7.83 at the end of the experiment. In clay loam soil; the $\mathrm{pH}$ value was initially 7.77 (Table 1) and ranged between 7.52-7.69 at the end of the study. The reason of reduced $\mathrm{pH}$ could be the application of the acid-based MAP and PS fertilizers during the experiment. HP treatment had the lowest $\mathrm{pH}$ value among all treatments for loam soil while both HP treatment and OPC had the lowest $\mathrm{pH}$ value for clay loam soil (Table 4). The $\mathrm{pH}$ value of HP was neutral. Research on four different super-absorbent polymers (SAP) showed that the effects of SAPs on soil $\mathrm{pH}$ and EC were contrary (Bai et al. 2010). $\mathrm{pH}$ values of the $\mathrm{P}$ and OPC applied soils were similar to that of the control soil. Hachicha et al. (2006) reported that compost made of olive oil wastes and poultry manure did not have any adverse effects on soil $\mathrm{pH}$ value. The lowest $\mathrm{pH}$ value was obtained from the OPC treatment for clay loam soil (Table 4). Nektarios et al. (2011) reported decrease in $\mathrm{pH}$ value as the compost was mixed into the soil. An initial EC value of loam soil was $115.80 \mu \mathrm{S} \mathrm{cm}^{-1}$ (Table 1) and it ranged between $437.50-878.33 \mu \mathrm{S} \mathrm{cm}^{-1}$ and the initial EC value was $201.90 \mu \mathrm{S} \mathrm{cm}^{-1}$ for clay loam soil (Table 1) and it ranged between 763.67-1475.33 $\mu \mathrm{S} \mathrm{cm}^{-1}$ at the end of the experiment. Application of soil conditioners increased EC values in both soil types (Table 4). On the other hand, EC values of both soil types classified as non-saline soil according to Richards' (1954). The highest EC value was observed in the OPC treatment $\left(1475.33 \mu \mathrm{S} \mathrm{cm}^{-1}\right)$ and the lowest EC was in the P treatment $\left(779.00 \mu \mathrm{S} \mathrm{cm}^{-1}\right)$ for loam soil. The results show that OPC decreased soil $\mathrm{pH}$ and increased EC at the end of the study. EC value of OPC was $2830 \mu \mathrm{S} \mathrm{cm}^{-1}$, it is possible to conclude that $\mathrm{EC}$ value increased in either loam soil or clay loam soil subsequent to the treatment. Increase of soil EC after the addition of olive pomace and OPC were also reported by Kavdır and Killi (2008) and Ntoulas et al. (2011).

Table 4. Effects of different soil conditioners on soil $\mathrm{pH}$ and EC

\begin{tabular}{lcccc}
\hline \multirow{2}{*}{ Treatments } & \multicolumn{2}{c}{$\mathbf{p H}(\mathbf{1 : 2 . 5})$} & \multicolumn{2}{c}{$\mathbf{E C}\left(\boldsymbol{\mu S} \mathbf{~ c m}^{\mathbf{- 1}}\right)$} \\
\cline { 2 - 5 } & Loam & Clay loam & Loam & Clay loam \\
\hline Control & $7.80 \pm 0.06 \mathbf{A}$ & $7.67 \pm 0.05 \mathbf{A}$ & $437.50 \pm 46.51 \mathbf{B}$ & $763.67 \pm 30.33 \mathbf{B}$ \\
Perlite & $7.83 \pm 0.07 \mathbf{A}$ & $7.69 \pm 0.05 \mathbf{A}$ & $476.33 \pm 94.66 \mathbf{B}$ & $779.00 \pm 59.27 \mathbf{B}$ \\
Olive pomace compost & $7.78 \pm 0.07 \mathbf{A}$ & $7.52 \pm 0.09 \mathbf{B}$ & $878.33 \pm 60.07 \mathbf{A}$ & $1475.33 \pm 45.90 \mathbf{A}$ \\
Hydrophilic polymer & $7.48 \pm 0.03 \mathbf{B}$ & $7.56 \pm 0.07 \mathbf{B}$ & $438.00 \pm 50.72 \mathbf{B}$ & $897.67 \pm 93.39 \mathbf{B}$ \\
\hline
\end{tabular}

Differences between the averages specified with different capital letters in the same column are significant and they indicate the difference between treatments $(\mathrm{n}=3, \mathrm{P}<0.05)$.

\section{Effects of different soil conditioners on plant growth and water use efficiency}

Treatments did not have significant effect on brunch numbers, height (Table 5) and weight (Table 6) of tomato plants in loam soil on the other hand their effects were found significant in clay loam soil $(\mathrm{P}<0.05)$. Plant fresh weight and height were the greatest in $\mathrm{P}$ treatment $(60.16 \mathrm{~cm}$ and 33.83 $\mathrm{g}$ respectively), the highest number of plant branches was found in the OPC (10.30) application in clay loam soil. However, the number of plant branches in P treatment is close to that of OPC treatment. Control soils had the lowest tomato fresh weight for both soil types. The highest tomato fresh weight was obtained from OPC treatment $(23.16 \mathrm{~g})$ while it was the lowest in control (10.14 g) treatment for 
loam soil, but this values were not statistically significant $(\mathrm{P}<0.05)($ Table 6). It is well known that additions of organic material to soils enhance plant growth. Cucci et al. (2008) applied $210 \mathrm{t} \mathrm{ha}^{-1}$ olive pomace to soil and soil organic matter increased 84\%. Montemurro et al. (2004) reported that applications of olive oil waste water and olive compost as an organic fertilizer increased rye-grass growth compared to unfertilized treatment. Co-composting products of olive oil processing wastewater and solid residue applied to soil $25 \% \mathrm{w} \mathrm{w}^{-1}$ and plants grown in these mixtures were $1.52-8.5 \%$ times larger than those grown on a sandy loam soil (Bouranis et al., 1995). Evans and Gachukia (2004) reported that tomato plants grown in perlite and sphagnum peat mixture containing $20 \%$ to $40 \%$ perlite had significantly higher dry shoot weights than those grown in same amount of fresh rice hullssphagnum peat mixture. Papafotiou et al. (2005) were placed OPC, peat and perlite in pots by mixing in different ratios. They reported that OPC is effective in increasing the height of the Ficus benjamina L. plant. Ozenc and Ozkan (2003) investigated the effects of peat and perlite addition to soil on the development of the pepper plant under water stress. Peat and perlite increased pepper development compared to soil alone.

Water use efficiency (WUE) as affected by different soil amendments are presented in Table 6. There was a decrease in tomato fresh weight and WUE in the control treatment compared to other treatments. WUE was the highest in OPC $\left(0.030\right.$ and $\left.0.040 \mathrm{~g} \mathrm{ml}^{-1}\right)$ and the least in control $(0.007$ and $0.010 \mathrm{~g} \mathrm{ml}^{-1}$ ) treatments for loam and clay loam soils (Table 6). P treatment has low water holding capacity therefore increasing the irrigation water can also improve plant growth under $\mathrm{P}$ treatment. Plant growth was enhanced by applications of OPC (Montemurro et al., 2004; Killi et al., 2014). Hydrophilic polymers did not effect on WUE thus López-Elías et al. (2013) observed no positive effects of polyacrylamide-based hydrophilic polymer (PAM) on WUE of plant.

Table 5. Plant branch number and plant height in different treatments

\begin{tabular}{|c|c|c|c|c|}
\hline \multirow{2}{*}{ Treatments } & \multicolumn{2}{|c|}{ Number of plant branches } & \multicolumn{2}{|c|}{ Plant height $(\mathrm{cm})$} \\
\hline & Loam & Clay loam & Loam & Clay loam \\
\hline Control & $8.00 \pm 0.00 \mathbf{A}$ & $8.0 \pm 0.00 \mathbf{B}$ & $42.50 \pm 8.50 \mathrm{~A}$ & $36.83 \pm 5.73 \mathbf{B}$ \\
\hline Perlite & $8.00 \pm 0.87 \mathbf{A}$ & $10.00 \pm 0.57 \mathbf{A}$ & $47.66 \pm 5.13 \mathbf{A}$ & $60.16 \pm 0.44 \mathbf{A}$ \\
\hline $\begin{array}{l}\text { Olive } \\
\text { compost }\end{array}$ & $8.60 \pm 0.33 \mathbf{A}$ & $10.30 \pm 0.66 \mathbf{A}$ & $50.83 \pm 3.09 \mathbf{A}$ & $47.66 \pm 5.13 \mathbf{B}$ \\
\hline Hydrophilic polymer & $9.60 \pm 0.66 \mathbf{A}$ & $7.00 \pm 0.57 \mathbf{B}$ & $48.66 \pm 3.38 \mathbf{A}$ & $39.00 \pm 2.65 \mathbf{B}$ \\
\hline
\end{tabular}

Differences between the averages specified with different capital letters in the same column are important and they indicate the difference between treatments $(n=3, P<0.05)$.

Table 6. Fresh weight and water use efficiency of tomatoe plants in different treatments

\begin{tabular}{|c|c|c|c|c|}
\hline \multirow{2}{*}{ Treatments } & \multicolumn{2}{|c|}{ Plants fresh weight $(\mathrm{g})$} & \multicolumn{2}{|c|}{ Water use efficiency $\left(\mathrm{g} \mathrm{ml}^{-1}\right)$} \\
\hline & Loam & Clay loam & Loam & Clay loam \\
\hline Control & $10.14 \pm 1.99 \mathbf{A}$ & $6.25 \pm 1.06 \mathbf{B}$ & 0.007 & 0.010 \\
\hline Perlite & $20.84 \pm 1.16 \mathbf{A}$ & $33.83 \pm 4.00 \mathbf{A}$ & 0.015 & 0.036 \\
\hline $\begin{array}{l}\text { Olive } \\
\text { compost }\end{array}$ & $23.16 \pm 5.97 \mathbf{A}$ & $26.64 \pm 5.45 \mathbf{A}$ & 0.030 & 0.040 \\
\hline Hydrophilic polymer & $15.98 \pm 2.57 \mathbf{A}$ & $6.78 \pm 0.87 \mathbf{B}$ & 0.012 & 0.013 \\
\hline
\end{tabular}

Differences between the averages specified with different capital letters in the same column are important and they indicate the difference between treatments $(\mathrm{n}=3, \mathrm{P}<0.05)$.

\section{Effects of different soil conditioners on plant root parameters}

Effect of soil conditioners on tomato root length and root surface area was statistically significant for both soil types. The highest root length was recorded in OPC applied soils. OPC significantly increased root length in a loam (186\%), and a clay loam (486\%) soils. Similarly, OPC also significantly increased root surface area by $212 \%$ and $392 \%$ in a loam and clay loam soil 
respectively (Table 7). Roots grown in HP treated soils showed the weakest development in a loam soil. Some researchers reported that hydrogel application reduced root and shoot growth of plants (Keever et al., 1989) and negatively affected plant growth (İşlek and Öztokat Kuzucu, 2018). In this research amended clay loam soil by OPC, P and HP enhanced plant root growth. OPC application increased root length by 5.9, 1.3, and 3.7 fold compared to control, P and HP treatments respectively, in a clay loam soil (Table 7). Killi et al (2014) also reported that root length and surface area increased with $8 \%$ OSWC application. OPC increased root surface area 3.1, 3.6, and 4.0-fold compared to control, $\mathrm{P}$ and HP treatments respectively in a loam soil.

Table 7. Plant root length and root area in different treatments

\begin{tabular}{lllll}
\hline \multirow{2}{*}{ Treatments } & \multicolumn{2}{c}{ Root length $(\mathrm{cm})$} & \multicolumn{2}{c}{ Root surface area $\left(\mathrm{cm}^{2}\right)$} \\
\cline { 2 - 5 } & Loam & Clay loam & Loam & Clay loam \\
\hline \multirow{2}{*}{ Control } & $469.80 \pm 87.26 \mathbf{B}$ & $155.30 \pm 60.02 \mathbf{B}$ & $41.07 \pm 3.50 \mathbf{B}$ & $13.07 \pm 2.33 \mathbf{C}$ \\
P & $469.30 \pm 105.42 \mathbf{B}$ & $704.80 \pm 214.36 \mathbf{B A}$ & $36.14 \pm 1.86 \mathbf{B}$ & $38.30 \pm 4.39 \mathbf{B}$ \\
OPC & $1345.40 \pm 404.53 \mathbf{A}$ & $910.60 \pm 165.52 \mathbf{A}$ & $128.28 \pm 0.92 \mathbf{A}$ & $64.38 \pm 1.78 \mathbf{A}$ \\
HP & $247.70 \pm 22.56 \mathbf{B}$ & $247.70 \pm 22.56 \mathbf{B}$ & $31.72 \pm 2.57 \mathbf{B}$ & $23.53 \pm 2.89 \mathbf{C B}$ \\
\hline
\end{tabular}

Differences between the averages specified with different capital letters in the same column are important and they indicate the difference between treatments $(n=3, P<0.05)$.

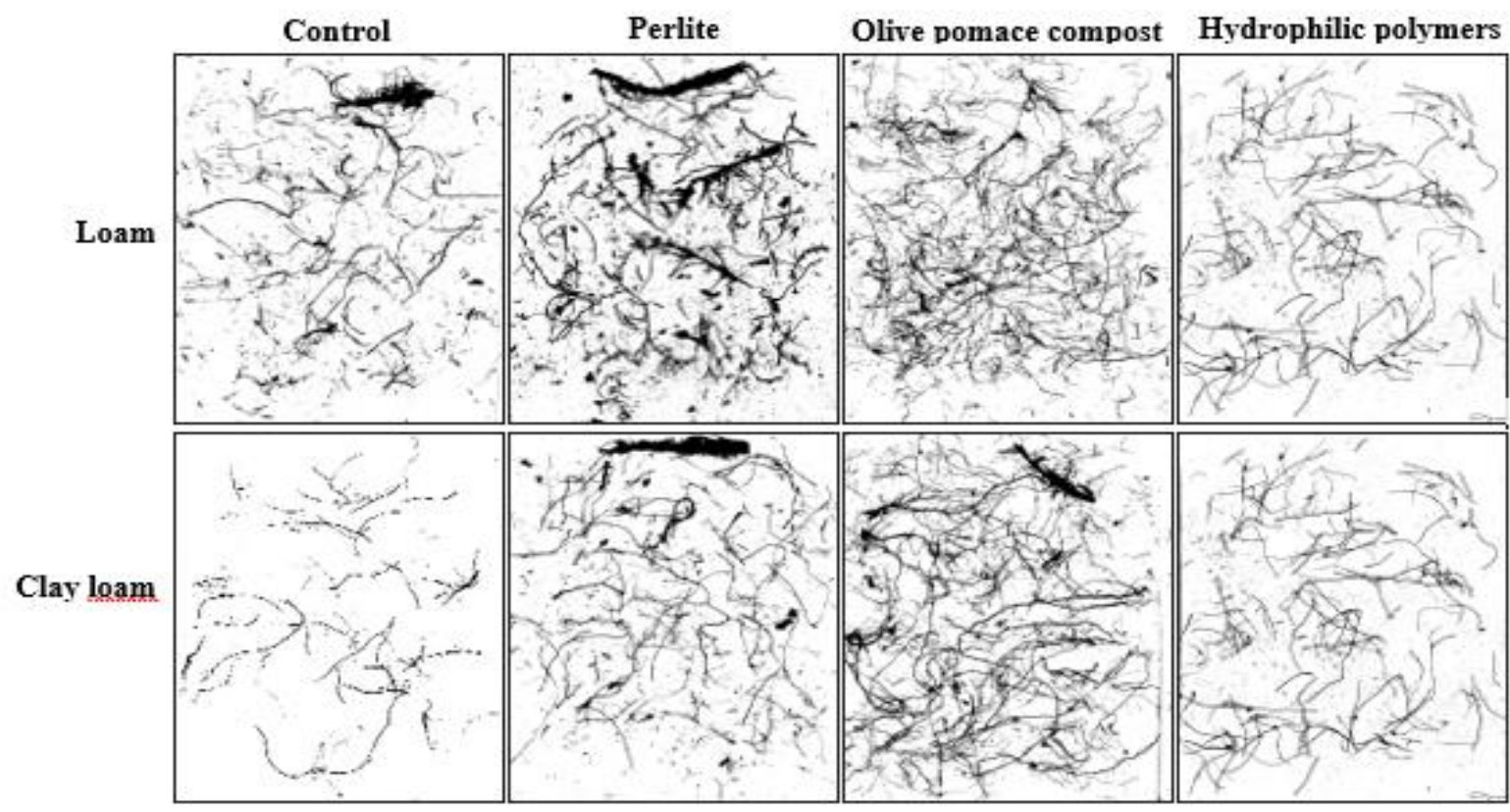

Figure 1. Plant root images of different applications in loam and clay loam soil

\section{Conclusion}

In this study, four different treatments including soil alone, $8 \%$ OPC, $4 \% \mathrm{P}$ and $0.12 \% \mathrm{HP}$ were used and replicated three times in loam and clay loam soils. Study was conducted under controlled atmosphere conditions and effect of soil water contents, $\mathrm{pH}$ and electrical conductivity, tomato plant growth (the number of branches and leaves, plant height, fresh and dry weights, plant water use efficiency, root parameters) and total irrigation water amount have been determined. Consequently; it is possible to conclude that P, HP and OPC which were mixed with soils conserved much more soil water compared to control soils. However; especially OPC preserved more water, increased tomato growth compared to other treatments in loam soils. Both tomato plants shoot and the root growth of OPC applied loam soil was significantly higher than those in the control treatment. Application of $\mathrm{P}$ increased tomato plant growth in clay loam soils but this material does not conserve water in the soil compared to other treatments. HP saved water in clay loam soil, but it had contributed the least to the development of tomatoes among other treatments. P, OPC and HP applications 
increased WUE by $114.29,328.57,71.43 \%$ respectively in loam soil and by $260.00,300.00,30.00$, respectively in clay loam soil compared to control treatment. In this research HP was applied at the rates of 1.7 and $1.6 \mathrm{t} \mathrm{ha}^{-1}$ while application rates of OPC were 114 and $104 \mathrm{t} \mathrm{ha}^{-1}$ for loam and clay loam soils, respectively. Cost of both amendments (HP and OPC) per year is nearly equal. Therefore, it can be suggested to apply OPC to the soil every year, since it increases plant water use efficiency and plant growth especially in loam soils compared to HP.

\section{Acknowledgments}

This article was produced from the MSc thesis of Nurten İşler' s entitled "Effects of different soil conditioners on soil water and modelling with Hydrus-2D. This research was funded by COMU BAP Project No. 2012/18.

\section{References}

Abedi-Koupai, J., Asadkazemi, J., 2006. Effects of a hydrophilic polymer on the field performance of cupressus arizonica under reduced irrigation regimes. Iranian Polymer Journal. 15(9):715-725.

Akhter, J., Mahmood, K., Malik, K. A., Mardan, A., Ahmad, M., Iqbal, M. M., 2004. Effects of hydrogel amendment on water storage of sandy loam and loam soils and seedling growth of barley, wheat and chickpea. Plant Soil and Environment. 50(10): 463-469.

Bai, W., Zhang, H., Liu, B., Wu, Y., Song, J., 2010. Effects of super-absorbent polymers on the physical and chemical properties of soil following different wetting and drying cycles. Soil Use and Management. 26(3): 253-260.

Black, C. A., 1965. Methods of Soil Analysis Part-II. American Soc. of Agronomy Inc., Publisher Madison Wisconsin, USA: 1372-1376.

Bouranis, D.L., Vlyssides, A.G., Drossopoulos, J.B., Karvouni, G., 1995. Some characteristics of a new organic soil conditioner from the co-composting of olive oil processing wastewater and solid residue. Communications in Soil Science and Plant Analysis. 26(15-16): 2461-2472.

Bowman, D.C., Evans, R.Y., 1991. Calcium inhibition of polyacrylamide gel hydration is partially reversible by potassium. HortScience. 26(8): 1063-1065.

Brady, N. C., Weil, R. R., 2008. The nature and properties of soils. 13: 662-710. Upper Saddle River, NJ: Prentice Hall.

Cardenas-Lailhacar, B.C., Dukes, M.D., 2010.Precision of soil moisture sensor irrigation controllers under field conditions. Agricultural Water Management. 97(5) 666-672.

Caron, J., Rivière, L.M., Guillemain, G., 2005. Gas diffusion and air-filled porosity: Effect of some oversize fragments in growing media. Canadian Journal of Soil Science. 85(1): 57-65.

Cucci, G., Lacolla, G., Caranfa, L., 2008. Improvement of soil properties by application of olive oil waste. Agronomy for sustainable development. 28(4): 521-526.

Demirel, K., Kavdır, Y., 2013. Effect of soil water retention barriers on turfgrass growth and soil water content. Journal of Irrigation Science. 31(4): 689-700.

El-Asswad, R. M., Said, A. O., Mornag, M. T., 1993. Effect of olive oil cake on water holding capacity of sandy soils in Libya Journal of arid environments. 24(4): 409-413.

Evans, M.R., Gachukia, M., 2004. Fresh parboiled rice hulls serve as an alternative to perlite in greenhouse crop substrates. HortScience. 39(2): 232-235.

Evans, M.R., Gachukia, M.M., 2007. Physical properties of sphagnum peat-based root substrates amended with perlite or parboiled fresh rice hulls. HortTechnology. 17(3): 312-315.

Fazackerley S. and Lawrence R., 2010. Reducing turfgrass water consumption using sensor nodes and an adaptive 1rrigation controller. Retrieved December 5, 2010, from: https//people.ok.ubc.ca/rlawrenc/research/Papers/IEEESAS2010.pdf. Accessed 10 Mar. 2012.

Gee, G.W., Bauder, J.W., 1986. Particle-size analysis. In: Klute, A. (Ed.), Methods of Soil Analysis, Part 1. Physical and Mineralogical Methods, 2nd ed. Agron. 9, American Society of Agronomy, Madison, WI: 383-413.

Gonzalez, M.D., Moreno, E., Quevedo-Sarmiento, J., Ramos-Cormenzana, A., 1990. Studies on antibacterial activity of waste waters from olive oil mills (alpechin): inhibitory activity of phenolic and fatty acids.Chemosphere. 20(3-4): 423-432.

Hachicha, S., Chtourou, M., Medhioub, K., Ammar, E., 2006. Compost of poultry manure and olive mill wastes as an alternative fertilizer. Agronomy for Sustainable Development. 26(2): 135-142.

Han, Y. G., Yang, P. L., Luo, Y. P., Ren, S. M., Zhang, L. X., Xu, L., 2010. Porosity change model for watered super absorbent polymer-treated soil. Environmental Earth Sciences. 61(6): 1197-1205.

Ilay, R., Kavdir, Y., Sümer, A., 2013. The effect of olive oil solid waste application on soil properties and growth of sunflower (Helianthus annuus L.) and bean (Phaseolus vulgaris L.). International 
Biodeterioration \& Biodegradation. 85: 254-259.

İşlek, M., Öztokat Kuzucu, C., 2018. Hidrojel-perlit karışımlarının salata (lactuca sativa var.crispa) yetiştiriciliğinde verim ve bazı kalite parametreleri üzerine etkilerinin belirlenmesi. ÇOMÜ Ziraat Fakültesi Dergisi. 6: 1-7.

Johnson, M.S., 1984. The effects of gel-forming polyacrylamides on moisture storage in sandy soils. Journal of the Science of Food and Agriculture. 35(11): 1196-1200.

Kavdir, Y., Killi, D., 2008. Influence of olive oil solid waste applications on soil pH, electrical conductivity, soil nitrogen transformations, carbon content and aggregate stability. Bioresource Technology. 99(7): 23262332.

Keever, G.J., Cobb G.S., Stephenson J.C. and Foster W.J., 1989. Effect of hydrophylic polymer amendment on growth of container grown landscape plants. J.Environ. Hort. 7 (2): 52-56.

Killi, D., Anlauf, R., Kavdir, Y., Haworth, M., 2014. Assessing the impact of agro-industrial olive wastes in soil water retention: Implications for remediation of degraded soils and water availability for plant growth. International Biodeterioration \& Biodegradation. 94: 48-56.

Leib, B.G., Jabro, J.D., Matthews, G.R., 2003. Field evaluation and performance comparison of soil moisture sensors. Soil Science 168 (6): 396-408

López-Elías, J., Huez, L., Rueda, P., Jiménez, L., Cruz, B., \& Garrido, L. (2013). Use of a hydrophilic polymer in Anaheim pepper (Capsicum annuum L.) under greenhouse conditions. Idesia, 31(2), 77-81.

Mazen, A.M., Radwan, D.E.M., Ahmed, A.F., 2013. Conditioning effect of different absorbant polymers on physical and chemical properties of sandy soil. Journal of Functional and Environmental Botany.3(2): 8293.

Montemurro, F., Convertini, G., Ferri, D., 2004. Mill wastewater and olive pomace compost as amendments for rye-grass. Agronomie. 24(8): 481-486.

Nektarios, P.A., Ntoulas, N., McElroy, S., Volterrani, M., Arbis, G., 2011. Effect of olive mill compost on native soil characteristics and tall fescue turfgrass development. Agronomy journal. 103(5): 1524-1531.

Ntoulas, N., Nektarios, P.A., Gogoula, G., 2011. Evaluation of olive mill waste compost as a soil amendment for Cynodon dactylon turf establishment, growth and anchorage. HortScience. 46(6): 937-945.

Orfánus, T., \& Eitzinger, J., 2010. Factors influencing the occurrence of water stress at field scale. Ecohydrology, 3(4): 478-486.

Ozenc, B. D., Ozkan, I., 2003. Effect of peat and perlite mixed with soil on growth of pepper plant (Capsicum annuum var. grossum cv. 11B-14) under water stress. Journal of Agricultural Sciences. 9(3): 305-312.

Papafotiou M., Kargas G., Lytra I., 2005. Olive-mill Waste Compost as a Growth Medium Component for Foliage Potted Plants. HortScience. 40(6): 1746-1750.

Richards, L.A., 1954. Diagnosis and improvement of saline and alkali soils. United States salinity laboratory staff. United States Department of Agriculture Handbook. 60-160.

Romano, N., Santini, A., 2002. Water retention and storage: Field. In "Methods of Soil Analysis, Part 4, Physical Methods". Dane, J.H., Topp, G.C., (Eds.), SSSA Book Series N.5, Madison, WI, USA: 721-738.

SAS, S., 1999. OnlineDoc ${ }^{\circledR}$, Version 8.SAS Institute, Cary, North Carolina. USA.

Starr, J.L., Paltineanu, I.C., 1998. Real-time soil water dynamics over large areas using multisensor capacitance probes and monitoring system. Soil and Tillage Research. 47(1-2): 43-49.

Starr, J.L., Paltineanu, I.C., 2002. Methods for measurement of soil water content: Capacitance Devices. In: Dane, J.H., Topp, G.C., (Eds.), Methods of Soil Analysis: Part 4, Physical Methods. Soil Science Society of America, Inc., Madison, WI. 463- 474.

Wallace, A., Wallace, G. A., 1986. Effects of very low rates of synthetic soil conditioners on soils. Soil Science. 141(5): 324-327.

Yang, L., Yang, Y., Chen, Z., Guo, C., Li, S., 2014. Influence of super absorbent polymer on soil water retention, seed germination and plant survivals for rocky slopes eco-engineering. Ecological Engineering. 62: 27-32.

Yurkov, A. L., Aksel'rod, L. M., 2005. Properties of heat-insulating materials (a review). Refractories and Industrial Ceramics. 46(3): 170-174. 